\title{
Financial and legal policy in the agricultural sector of the region and features of its implementation
}

\author{
Natalya Panova ${ }^{1 *}$, Alexander Malofeev ${ }^{1}$, Aleksey Voronkin $^{1}$, Evgeny Likholetov ${ }^{1}$, and \\ Alexander Likholetov ${ }^{2}$ \\ ${ }^{1}$ Volgograd State Agrarian University, Universitetskiy Prospect 26, 400002, Volgograd, Russia \\ 2 Volgograd Academy of the Russian Internal Affairs, Istoricheskaya Str. 130, 400048,Volgograd, \\ Russia
}

\begin{abstract}
The article is devoted to the formation of financial policy in the field of agro-industrial complex, in its economic and social aspects, the main goals, elements and directions of development at the present stage. The article considers the main directions of financial policy in the agricultural sector using the example of the Volgograd region, which is one of the leading regions of the southern Federal district in terms of agricultural planning, economics and engineering. The article concludes that at the moment, the region has chosen a liberal model of financial policy that offers the maximum package of incentives for agribusiness. At the same time, the article also identified existing problems in the system of formation and implementation of financial and legal policy in the agricultural sector of the region, as well as outlined possible ways to solve them by modernizing the budget process, ensuring the stability of the regional budget and its balance in the long term, improving the efficiency of Executive authorities and state institutions.
\end{abstract}

\section{Introduction}

Financial policy is a purposeful activity of the state and other economic entities in the sphere of formation, distribution and use of financial resources to achieve this goal and reflects the subjective side of the functioning of Finance [1].

Financial policy is part of the socio-economic policy that determines the social stability and integrity of the state, since any ill - considered change or weakening of it leads to an increase in threats to the sustainability of development, reducing the levels of components of national security-financial, economic, energy, investment, innovation, and food security.

The processes of organizing financial relations and cash flows, as well as the mechanism of functioning of Finance, do not work on their own. Their they are organized by specific actors who are guided by economic, political and humanitarian factors. At the same time, common interests are combined with the personal interests of these subjects. As

\footnotetext{
*Corresponding author: panov181208@ mail.ru
} 
a result, financial policy is always an interweaving of different interests imperious structures and individual political parties, local and Central government bodies, entrepreneurs, investors, consumers and various segments of the population [2].

The content of financial policy is a multi-faceted process and can be represented as a unity of three components, such as:

- development of scientifically based concepts for financial development;

- defining the main directions of using Finance for the current period and for the future;

- implementation of practical actions to achieve the goals set.

Depending on the level of implementation, there are: level);

- financial policy of international organizations and financial institutions (international

- the financial policy of the state (macro level);

- financial policy of the region (meso-level);

- financial policy of the business entity.

At the same time, priority is given to the implementation and development of the state's financial policy, that is, the macro-level financial policy, which is a set of measures to use financial relations to perform the state's functions. It specifies the main directions of development of the national economy, determines the total amount of financial resources, their directions of use and sources, develops a mechanism for stimulating socio-economic processes by financial methods and regulating these processes [3].

The financial policy of the meso-level, that is, the financial policy of the region acts as one of the most important components of the financial policy of the state as a whole. This policy is implemented within the country's subjects within their competence in matters of legislative regulation, management and organization of financial flows. [4] the finances of the subjects of the Russian Federation are a set of monetary relations arising from the formation, use and distribution of regional funds of financial resources for solving both social and economic problems of the region. These relations are formed between the state authorities of the subjects of the Russian Federation and the population living on the territory of this subject, as well as economic entities that are part of the regional economy.

\section{Materials and methods}

The object of the research is the financial policy implemented at the regional level. The subject of the research is the specifics of the budget and tax policy of the Volgograd region, as well as its main directions. As the main approach to the study, the dialectical approach is used as the only correct one at the present time. At the empirical level, methods of economic statistics, analysis, and synthesis are used. The application of the evolutionary method at the stage of transition from the empirical to the theoretical level of research is justified, since the processes of developing and analyzing the results of financial policy at the regional level are possible only after passing a certain time interval.

\section{Results}

The financial policy of the region is focused and based on the implementation and use of financial resources of this territorial entity, in the structure of which are allocated: the budget of the subject; regional extra-budgetary funds; state securities owned by state authorities of the region; other funds owned by the territorial entity.

Each type of financial policy is quite independent, and as a result, it has its own tasks and implementation tools. The tasks of regional financial policy by type are presented in table 1 . 
Table 1 - Tasks of regional financial policy in the context of its types.

\begin{tabular}{|l|l|}
\hline \multicolumn{1}{|c|}{$\begin{array}{c}\text { Type of financial } \\
\text { policy }\end{array}$} & \multicolumn{1}{c|}{ Tasks of the financial policy subspecies } \\
\hline $\begin{array}{l}\text { 1. Tax policy of the } \\
\text { region }\end{array}$ & $\begin{array}{l}\text { Achieving a balance of centralized and decentralized financial } \\
\text { resources, ensuring conditions for the use of decentralized financial } \\
\text { resources for the implementation of the goals of social and economic } \\
\text { development of the region. }\end{array}$ \\
\hline $\begin{array}{l}\text { 2. Fiscal policy at the } \\
\text { regional level }\end{array}$ & $\begin{array}{l}\text { The establishment of the rational allocation and use of financial } \\
\text { resources of the centralized type. }\end{array}$ \\
\hline $\begin{array}{l}\text { 3. Investment policy of } \\
\text { the region }\end{array}$ & $\begin{array}{l}\text { Providing incentives and regulation of investment-related activities, } \\
\text { creating prerequisites for increasing the level of investor activity. }\end{array}$ \\
\hline $\begin{array}{l}\text { 4. Pricing policy at } \\
\text { regional level }\end{array}$ & $\begin{array}{l}\text { Organization of the tariff regulation process by taking into account } \\
\text { regional specifics. }\end{array}$ \\
\hline $\begin{array}{l}\text { 5. Regional policy of } \\
\text { state property } \\
\text { management }\end{array}$ & Creating conditions for the efficient use of state property. \\
\hline
\end{tabular}

Federal legislation defines a set of implementation tools for each type of financial policy in the region, but the authorities of the Federal subject can choose which tools they can and will use in the practical implementation of the financial policy of the region [5].

The instruments of regional financial policy in the context of its individual types are presented in table 2 .

Table 2 - Tasks of regional financial policy in the context of its types.

\begin{tabular}{|c|c|}
\hline Types of regional financial policy & Tools \\
\hline 1. Tax policy of the region & $\begin{array}{l}\text { - introduction of regional taxes; } \\
\text { - establishment of differentiated rates; } \\
\text { - establishment of additional tax benefits at the regional level; } \\
\text { - determination of the terms of payment of regional taxes; } \\
\text { - change of tax payment terms. }\end{array}$ \\
\hline $\begin{array}{l}\text { 2. Fiscal policy at the regional } \\
\text { level }\end{array}$ & $\begin{array}{l}\text { - consideration of expenditure directions of budget funds; } \\
\text { - provision of state guarantees; } \\
\text { - attraction of budget loans, loans from credit organizations; } \\
\text { - implementation of the issue of securities. }\end{array}$ \\
\hline 3. Investment policy of the region & $\begin{array}{l}\text { - providing tax incentives to investors; } \\
\text { - implementation of state guarantees; } \\
\text { - implementation of capital expenditures; }\end{array}$ \\
\hline 4. Pricing policy at regional level & $\begin{array}{l}\text { - allocation of subventions; } \\
\text { - establishment of additional benefits; } \\
\text { - tariff regulation. }\end{array}$ \\
\hline $\begin{array}{l}\text { 5. Regional policy of state } \\
\text { property management }\end{array}$ & $\begin{array}{l}\text { - privatization; } \\
\text { - implementation of budget grants, subventions, subsidies; } \\
\text { - provision of budget loans; } \\
\text { - implementation of state guarantees; } \\
\text { - placing orders of the state; } \\
\text { - introduction of paid services; } \\
\text { - implementation of price tariff regulation; } \\
\text { - establishment of additional benefits. }\end{array}$ \\
\hline
\end{tabular}

The financial policy of the region is based on the programs of its economic and social development and is aimed at:

- to increase the investment attractiveness of the region;

- development of regional financial markets;

- increasing the financial security of the region;

- fulfillment of financial obligations of the subject of the Russian Federation; 
- ensuring the balance of municipal and consolidated regional budgets. [6]

Thus, the financial policy of the region acts as the basis for implementing its economic policy and the basis for improving the quality of life of the population living on its territory.

We will assess the financial policy of the Volgograd region, which is one of the most dynamically developing industrial and agricultural regions of the southern Federal district of the Russian Federation, and is quite attractive to domestic and foreign investors. In terms of gross regional product, the region ranks 26th among 85 subjects of the Russian Federation.

In 2018, the economy of the Volgograd region as a whole showed positive trends in most production and economic indicators. The turnover of organizations in 2018 amounted to 2.2 trillion rubles, which in current prices is $7.2 \%$ more than in 2016 . The growth of turnover was provided by enterprises and organizations of most types of economic activity (Fig. 1). The index of industrial production in the region in 2018 decreased by $0.4 \%$ compared to the level of 2016 and amounted to $101.7 \%$. According to this indicator, the Volgograd region is among the outsiders of the southern Federal district, but corresponds to the average Russian level. During the period from 2016 to 2018, the production volumes of most of the main types of industrial activities were increased [7].

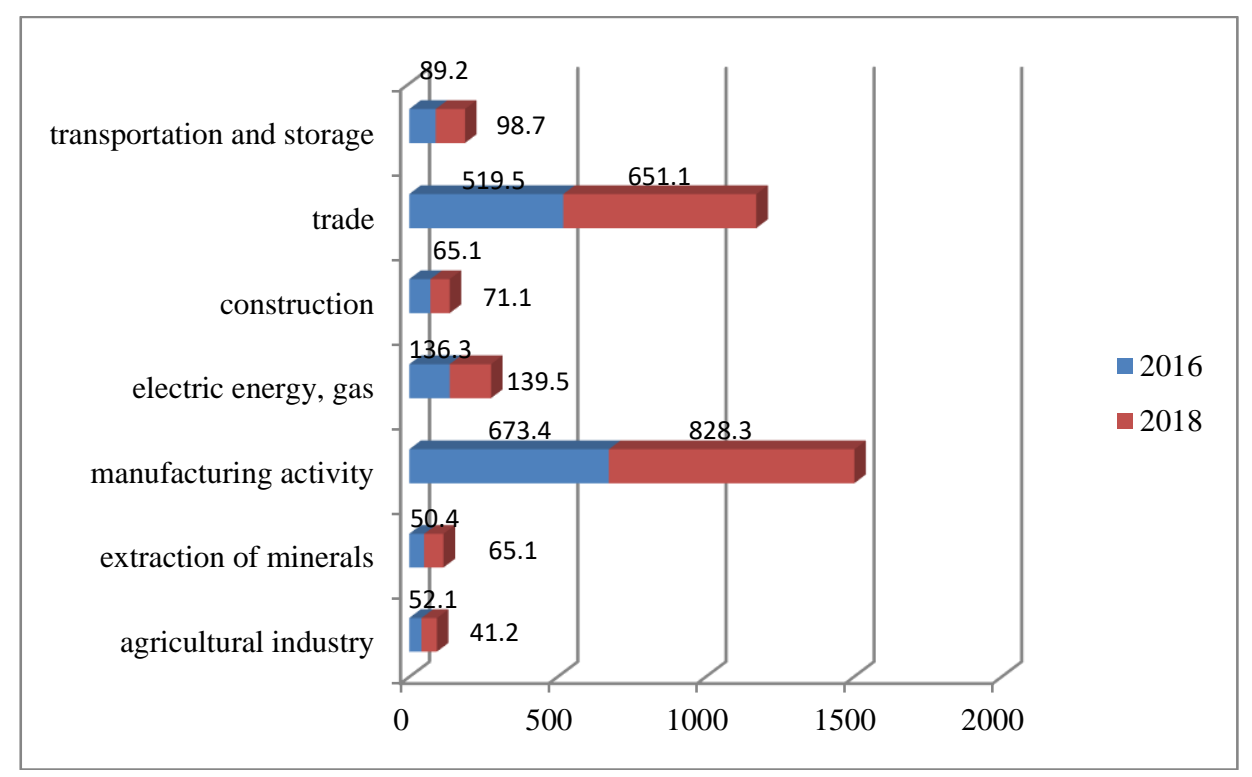

Fig. 1. Turnover of organizations by defining types of economic activity (billions of rubles).

Manufacturing enterprises in the region were particularly distinguished, with an index of $111.6 \%$, while the national average was $103.8 \%$. Also, excellent results were shown by organizations of the machine-building complex, which doubled the volume of production of vehicles, machinery and equipment. The growth of production of chemicals and products by $2.5 \%$ was provided by Volgograd manufacturers of the chemical industry, the growth of medicines was $14.6 \%$. Good dynamics was also noted in the production of plastics in primary forms - plus $3.2 \%$ and plastic vials $-2.8 \%$, caustic soda $-1.3 \%$. The output of finished metal products of the metallurgical complex increased by $44 \%$. In addition, the output of asphalt concrete mixes increased 1.6 times: bricks - by $34.4 \%$, cement - by $22.6 \%$; ceramic tiles for internal wall cladding - by $17.5 \%$; building blocks-by $8 \%$; gypsum-by $5.9 \%$. In the oil refining complex, there is an increase in the production of coke and petroleum products. 
In 2018, companies in the following areas and industries had a decisive impact on profit formation:

- manufacturing - 55 billion rubles ( $37.4 \%$ of the total volume);

- wholesale and retail trade - 132 billion rubles $(29.4 \%)$;

- mining - 15 billion rubles $(2.9 \%)$.

The Volgograd region was one of the first regions of the southern Federal district to take the initiative to develop a regional financial policy that assumes the maximum package of incentives for investors, which is enshrined in the relevant norms of regional legislation, namely:

- preferential taxation of investment infrastructure organizations and investors involved in attracting investment;

- direct financing from the regional budget or co-financing of investment projects through the use of specially formed joint-stock investment funds;

- partial insurance of non-commercial risks and interest rate subsidies;

- improving the conditions for investors, including organizing the process of financing infrastructure in the region through the Federal budget and international organizations. [8]

At the same time, the following factors influence the formation of the financial policy of the region:

- competitive advantages of the Volgograd region;

- the process of creating a favorable investment climate;

- managing investment attractiveness of the region;

- development of public-private partnerships;

- support for innovative financial activities;

- economic interest of subjects and objects of the political process. [9]

The financial policy of the Volgograd region, along with positive aspects, has certain problems in the system of its formation and subsequent implementation. These include:

- insufficient responsibility and independence of regional authorities in the implementation of their budget and spending powers;

- local budget openness, accountability and transparency of the functioning of participants in the public administration sector;

- low level of involvement of civil society in the process of discussing the results and goals of using budget funds;

- insufficient activity of strategic investors due to incomplete information about investment opportunities in the Rostov region;

- limited access to credit-type resources and other long-term financing instruments;

- low internationalization of business. [10]

These problems hinder the effective development of the financial policy of the region, and, consequently, the effective development of the economy of the Volgograd region as a whole. Overcoming the above-mentioned problems in the sphere of formation and implementation of the financial policy of the region is possible through the implementation of the Volgograd region state program "public Finance Management of the Volgograd region" for the period up to 2022 .

The goal of the Program is to increase the efficiency, accountability and transparency of the budget use process, as well as to improve the procedure for implementing financial control by the state. The program defines the General mechanisms for achieving the results of state programs in the Volgograd region.

This program is aimed at implementing promising areas of financial policy in a region such as the Volgograd region, taking into account the realities of the current economic situation. The promising areas of implementation of the financial policy of the Rostov region, in turn, should include such as (Fig. 2). 


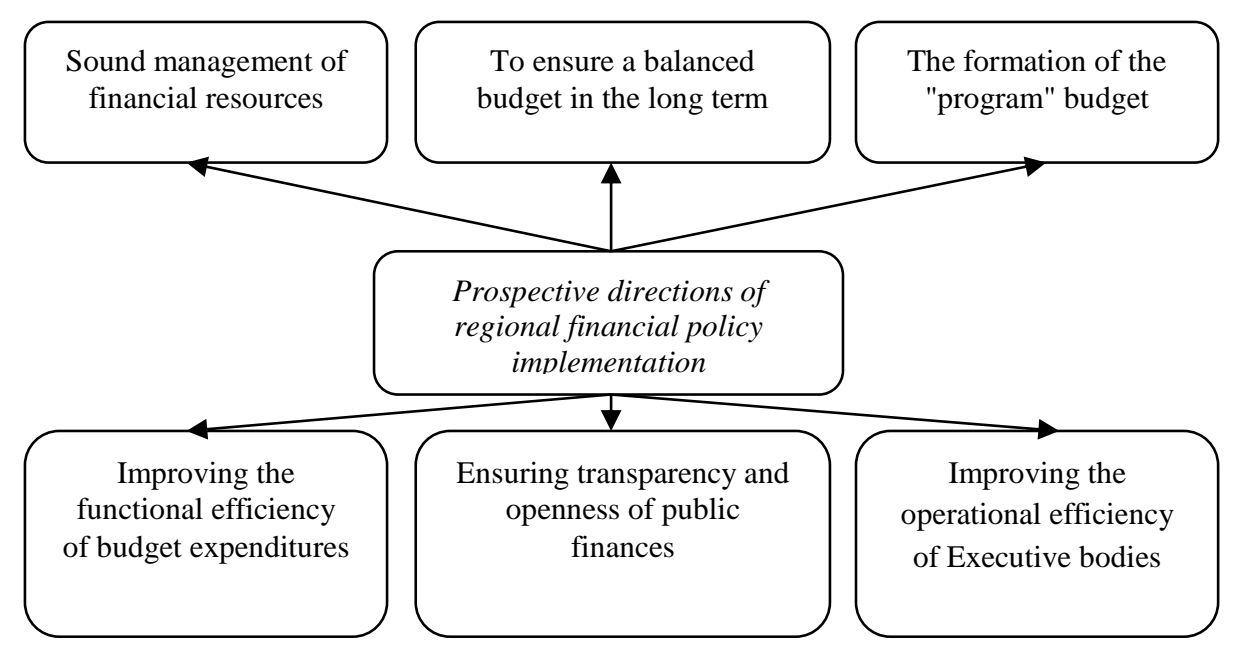

Fig. 2. Prospective directions of financial policy implementation in the Volgograd region.

The implementation of the above-mentioned financial policies in the subject of the Russian Federation will ultimately contribute to the progressive growth of the region's economy.

\section{References}

1. A. Panov, N. Panova, G. Zvereva, T. Daeva, A. Mozgovoy, A. Beskopilniy, E3S Web of Conferences, 135, 01099 (2019)

2. M. Chang, Journal of International Economics, 122, 103259 (2020)

3. A.S. Ovchinnikov, N.V. Ivanova, N.N. Balashova, Espacios, 39(36), 14 (2018)

4. T.N. Litvinova, Advances in Intelligent Systems and Computing, 622, 284-290 (2018)

5. L.V. Popova, D.A. Korobeynikov, O.M. Korobeynikova, A.A. Panov, Journal of Applied Economic Sciences, 11(6) , 1034-1044 (2016)

6. A. Nawab, F. Ibtisham, G. Li, B. Kieser, L. An, Journal of Thermal Biology, 78, 131139 (2018)

7. R. Matousek, E. Panopoulou, A. Papachristopoulou Journal of Corporate Finance, 62, 101558 (2020)

8. R.N. Murtazayeva, G.N. Zvereva, D.A. Grebneva, Proc. of the Lower Volga AgroUniversity Comp., 3(55), 235-244 (2019)

9. G. Georgiadis, A. Mehl, Journal of International Economics, 103, 200 -212 (2016)

10. A. Singh, S. Stone, J. Suda, Economics Letters, 132, 82-86 (2015) 